\title{
Análise do Reconhecimento da União Homoafetiva como Instituto Jurídico, pelo Supremo Tribunal Federal, à luz da Declaração Internacional sobre o Direito ao Desenvolvimento.
}

João Paulo Falavinha Marcon'1

\section{RESUMO}

Em 2011, o Supremo Tribunal Federal Brasileiro, em julgamento inédito e pioneiro, reconheceu validade jurídica à união homoafetiva. Tal decisão pode ser compreendida pelos valores e princípios norteadores do Estado de Direito Brasileiro contemporâneo, os quais abrangem diversos preceitos insculpidos na Declaração Internacional sobre o Direito ao Desenvolvimento, aprovada pela Assembleia Geral da ONU, em 1986.

Palavras-chave: STF; ONU; Homoafetividade; Direito; Desenvolvimento

Em 05/05/2011, o Supremo Tribunal Federal, instância máxima do Poder Judiciário brasileiro e "guardião" da Constituição, julgou a ação denominada "Arguição de Descumprimento de Preceito Fundamental 132/RJ", impetrada pelo Governo do Estado do Rio de Janeiro.

O autor alegou, em síntese, (I) que determinadas disposições constantes no Estatuto dos Servidores Civis do Estado citado, por via interpretativa, reduziriam direitos de indivíduos com orientação sexual voltada a pessoas do mesmo gênero; (II) que decisões judiciais proferidas naquele Estado e em outras unidades da Federação deixavam de reconhecer vários direitos eleitos pela Carta Magna, às uniões homoafetivas, limitando-os às relações heterossexuais; (III) tal situação constituiria violação direta aos princípios fundamentais da igualdade, segurança jurídica, liberdade, dignidade da pessoa humana e razoabilidade (ou proporcionalidade).

\footnotetext{
${ }^{1}$ Advogado, especialista em Direito Internacional e Negócios Internacionais, mestrando pelo Programa de Pós-Graduação Stricto Sensu em Ciência Política da UFPR, pesquisador do Núcleo de Estudos e Pesquisas em Relações Internacionais (NEPRI) e membro da Comissão de Direito Internacional da OAB/PR.
} 
Ao final, o acionante pugnou pela utilização do método analógico, devidamente permitido em Direito, para fins de equiparação das uniões estáveis homoafetivas, às igualmente duradouras que se estabelecem entre indivíduos de sexos opostos, contanto que as primeiras visassem à formação de unidade autônoma doméstica, ou seja, uma entidade familiar.

Os Ministros componentes da Suprema Corte votaram, unanimemente, a favor do deferimento do pleito autoral, atribuindo, a esta decisão, eficácia erga omnes (quando os efeitos atingem todos os indivíduos de uma determinada população ou membros de uma organização, para o direito nacional) e efeito vinculante (é aquele pelo qual a decisão tomada por um tribunal em determinado processo passa a valer para os demais que discutam questão idêntica. No STF, a decisão tomada em Ação Direta de Inconstitucionalidade, Ação Declaratória de Constitucionalidade ou na Arguição de Descumprimento de Preceito Fundamental possui tal efeito, ou seja, deve ser aplicada a todos os casos sobre o mesmo tema).

O conteúdo decisório, bem como a homogeneidade de posicionamento dos Membros do Tribunal Supremo, surpreendeu vários segmentos da sociedade e baseouse em diversos preceitos (princípios e normas) norteadores das relações sociais eleitos pelos legisladores constituintes originários, como se passa a demonstrar.

A Constituição Cidadã de 1988 alçou à categoria de direito fundamental da pessoa humana a proibição de discriminação em razão do sexo, o que não deve ser somente entendido na dicotomia homem/mulher, mas também no plano da orientação sexual de cada qual. Tal vedação resulta da opção pelo Constitucionalismo Fraternal, em homenagem ao pluralismo, como axioma sócio-político-cultural².

Assim, todos os indivíduos têm plena liberdade para dispor de sua sexualidade, posto que tal prerrogativa insere-se na categoria de direitos fundamentais do ser humano, já que representa manifestação de sua autonomia da vontade. Esta, por sua vez, constitui uma das cláusulas pétreas constitucionais (limitações materiais ao poder de

\footnotetext{
2 "O chamado constitucionalismo fraternal significa a última etapa do constitucionalismo na humanidade. Passa por uma fase de fundação chamada de Estado Liberal ou Constitucionalismo Liberal, se apresenta numa fase intermediária, tempos depois, na fundação da social democracia, e chega à terceira e virginal fase da evolução, que tem como elemento mais relevante a solidariedade expressa na fraternidade, isto é, o constitucionalismo fraternal. Isso significa dizer que o lema da revolução francesa chega a ser concluído de fato quando os Estados passam a consubstanciar, em suas cartas magnas valores supremos e especificamente indicam, de forma expressa, a solidariedade ou fraternidade como valor a ser perseguido."

Conjuntura Global, Curitiba, Vol. 1, n.1, jul./set., 2012, p. 18-21. 
reforma da Constituição de um Estado. Em outras palavras, são disposições que proíbem alterações, por meio de emenda, tendentes a abolir as normas constitucionais relativas às matérias por elas definidas).

Nessa esteira, o sexo das pessoas, salvo disposição constitucional expressa ou implícita em sentido contrário, não se presta à realização de diferenciações jurídicas, em decorrência do objetivo constante na Lei Maior de "promover o bem de todos". Ademais, cumpre ressaltar que este documento incorporou a "norma geral negativa" kelseniana que dispõe: “o que não estiver juridicamente proibido, ou obrigado, está juridicamente permitido". Seguindo esse raciocínio, a Constituição Federal não veda a formação de famílias por pessoas do mesmo sexo, porquanto "não se proíbe nada a ninguém senão em face de um direito ou de proteção de um legítimo interesse de outrem, ou de toda a sociedade, o que não se dá na hipótese sub judice".

Outra razão a consubstanciar o argumento decisório emanado pelo Pretório Excelso encontra guarida no parágrafo $2^{\circ}$, do artigo $5^{\circ}$ da Constituição Federal, que dispõe: "Os direitos e garantias expressos nesta Constituição não excluem outros decorrentes do regime e dos princípios por ela adotados, ou dos tratados internacionais em que a República Federativa do Brasil seja parte”.

Da leitura retro, vislumbra-se, claramente, a possibilidade de recepção, na legislação constitucional pátria, de direitos e garantias oriundos de documentos internacionais. Assim, insere-se a Declaração sobre o Direito ao Desenvolvimento, adotada pela Resolução $\mathrm{n}^{\circ}$ 41/128 da Assembleia Geral das Nações Unidas, em 04/12/1986, a qual visa, dentre outros fins, a "promover e encorajar o respeito aos Direitos Humanos e às liberdades fundamentais para todos, sem distinção de raça, sexo, língua ou religião".

Mister, ainda, ressaltar:

Preocupada com a existência de sérios obstáculos ao desenvolvimento, assim
como à completa realização dos seres humanos e dos povos, constituídos, inter
alia, pela negação dos direitos civis, políticos, econômicos, sociais e culturais, e
considerando que todos os direitos humanos e as liberdades fundamentais são
indivisiveis e interdependentes, e que, para promover o desenvolvimento,
devem ser dadas atenção igual e consideração urgente à implementação,
promoção e proteçãa dos direitos civis, políticos, econômicos, sociais e
culturais, e que, por conseguinte, a promoção, o respeito e o gozo de certos
direitos humanos e liberdades fundamentais não podem justificar a
negação de outros direitos humanos e liberdades fundamentais. 
Cotejando-se as razões de decidir apresentadas pelos Ministros componentes do Supremo Tribunal Federal e as disposições que se acabaram de reproduzir, constata-se a absorção, no ordenamento jurídico brasileiro, de diversos valores, princípios, direitos, garantias e regras que já se haviam prestigiado antes mesmo da promulgação da Constituição (em 1988). Logo, pode-se afirmar que o conjunto normativo-axiológico do Estado Democrático de Direito Brasileiro Contemporâneo está em consonância com várias das linhas de orientação internacionais. Isso é de fundamental importância em um país que, reiteradamente, tem afirmado seu desejo em ser um ator mundial mais proeminente e relevante, afinal, não só para se inserir no sistema, mas também para se ter legitimidade, é imprescindível que o Estado adeque-se a ele, bem como cumpra, materialmente, as obrigações assumidas perante tal sistema.

Destarte, vê-se que, a decisão proferida pelo STF, não apenas atendeu ao princípio da legalidade e ao que dispõe a Declaração sobre o Direito ao Desenvolvimento, como também demonstrou estar, o Brasil, cada vez mais alinhado aos seus parceiros democráticos mundiais e às tentativas de harmonização das normas internacionais, bem assim tem, crescentemente, garantido o uso e gozo de direitos inerentes a todo e qualquer ser humano, sem distinções de qualquer ordem.

\section{Referências Bibliográficas}

CONSTITUIÇÃO DA REPÚBLICA FEDERATIVA DO BRASIL. Disponível em http://www.planalto.gov.br/ccivil 03/constituicao/constitui\%C3\%A7ao.htm. Acesso em 25/07/2012.

ORGANIZAÇÃO DAS NAÇÕES UNIDAS. Declaração sobre o Direito ao Desenvolvimento. Disponível em http://www.un.org/documents/ga/res/41/a41r128.htm. Acesso em 25/07/2012.

SUPREMO TRIBUNAL FEDERAL. ARGÜIÇÃO DE DESCUMPRIMENTO DE PRECEITO FUNDAMENTAL $132 \quad R I O \quad D E \quad$ JANEIRO. Disponível em http://www.stf.jus.br/portal/geral/verPdfPaginado.asp?id=433816\&tipo=TP\&desc ricao=ADPF\%2F132. Acesso em 25/07/2012. 